Supporting Information for

\title{
One-Step High-Throughput Telomerase Activity Measurement of Cell Populations, Single Cells, and Single Enzyme Complexes
}

\author{
Ke-wei Zheng ${ }^{1,2, \#}$, Chao Liü ${ }^{3, \#}$, Qing Meng ${ }^{2}$, Yu-hua Hao ${ }^{2}$, Jin-ping Zheng ${ }^{4}$, Wei Li $^{3, *}$, Zheng \\ $\operatorname{Tan}^{2,4, *}$ \\ ${ }^{1}$ School of Pharmaceutical Sciences (Shenzhen), Sun Yat-Sen University, Guangzhou 510275, \\ P.R. China \\ ${ }^{2}$ State Key Laboratory of Membrane Biology, ${ }^{3}$ State Key Laboratory of Stem cell and \\ Reproductive Biology, Institute of Zoology, Chinese Academy of Sciences, Beijing 100101, P. R. \\ China \\ ${ }^{4}$ Center for Healthy Aging, Changzhi Medical College, Changzhi 046000, Shanxi, P. R. China \\ ${ }^{\#}$ Contributed equally to the work \\ *To whom correspondence should be addressed: \\ liwei@ioz.ac.cn (W.L.) or z.tan@ioz.ac.cn (Z.T.)
}

Keywords: TRAP, Telomerase assay, cancer, Single cell analysis, Single molecule analysis 


\section{Supporting Table and Figures}

Table S1. Comparisons of TRAP assay variants.

\begin{tabular}{|c|c|c|c|c|}
\hline Method of Assay & Sensitivity (Cells) & Linear range (Cells) & Source of Signal & Reference \\
\hline SES-TRAP & $\begin{array}{l}\text { Single telomerase } \\
\text { complex }\end{array}$ & $\begin{array}{l}\text { Single telomerase } \\
\text { complex - } 20000\end{array}$ & $\begin{array}{l}\text { Fluorescent } \\
\text { primer }\end{array}$ & This work \\
\hline TRAP-PAGE & 10 & NA & $\begin{array}{l}{ }^{32} \mathrm{P} \text { Radioactive } \\
\text { isotope }\end{array}$ & 1 \\
\hline TRAP-PAGE with IS & 1 & $10-3000$ & $\begin{array}{l}{ }^{32} \mathrm{P} \text { Radioactive } \\
\text { isotope }\end{array}$ & 2 \\
\hline F-TRAP & 100 & NA & $\begin{array}{l}\text { Fluorescent } \\
\text { Primer }\end{array}$ & 3 \\
\hline $\begin{array}{l}\text { TRAP-PAGE with } \\
\text { fluoresent staining }\end{array}$ & 10 & $10-300$ & EB Staining & 4 \\
\hline $\begin{array}{l}\text { TRAP-PAGE with } \\
\text { Silver staining }\end{array}$ & 10 & NA & Silver staining & 5 \\
\hline TRAP-SPA & 10 & NA & $\begin{array}{l}{ }^{3} \mathrm{H} \text { Radioactive } \\
\text { isotope }\end{array}$ & 6 \\
\hline TRAP-HPA & 10 & $10-1000$ & AE-labeled probe & 7 \\
\hline $\begin{array}{l}\text { TRAP with } \\
\text { amplifluore primers }\end{array}$ & $10-50$ & $10-10000$ & $\begin{array}{l}\text { Fluorescent } \\
\text { primer }\end{array}$ & 8 \\
\hline $\begin{array}{l}\text { TRAP combined with } \\
\text { ELISA }\end{array}$ & 10 & NA & ELISA & 9 \\
\hline Real-time TRAP & 50 & $10-2000$ & $\begin{array}{l}\text { Fluorescent } \\
\text { primer }\end{array}$ & 10 \\
\hline
\end{tabular}




\section{FMTS Dimer: 5'-AGCATCCGTCGAGCAGAGTT-3'

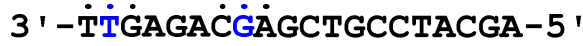 \\ FOTS Dimer: 5'-AGCATCCGTCACCGAGAGTT-3' 3 ' - $\dot{T} T \dot{T} A G A G \dot{C} C \dot{C} C T G C C T A C G A-5$ '}

Figure S1. Base-pairing at the 3' end of potential self-dimer of the FMTS and FOTS primer. Letters in blue indicate wobble base pairs.

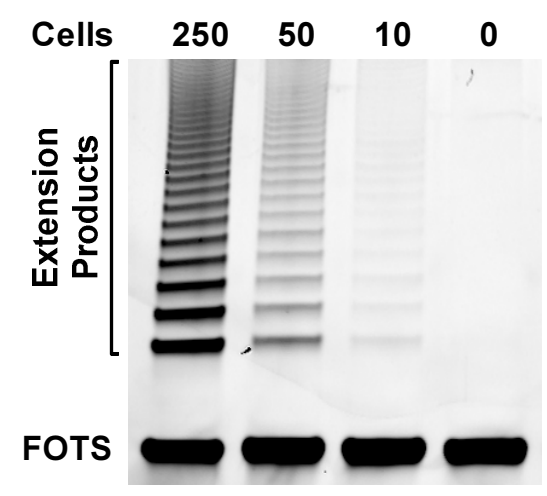

Figure S2. Polyacrylamide gel electrophoresis showing telomerase extension products obtained with the indicated number of HeLa cell extract and amplified with the FOTS/ACX primer pair in a TRAP assay. 

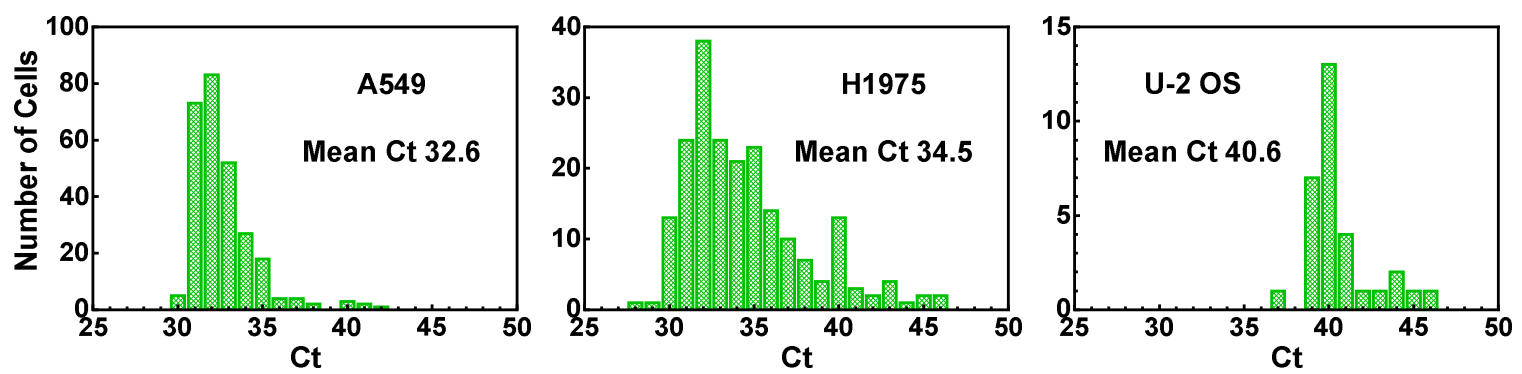

Figure S3. Distribution of telomerase activity in single A549, H1975, and U-2 OS cells. Measurements were carried out as in Figure 3B.

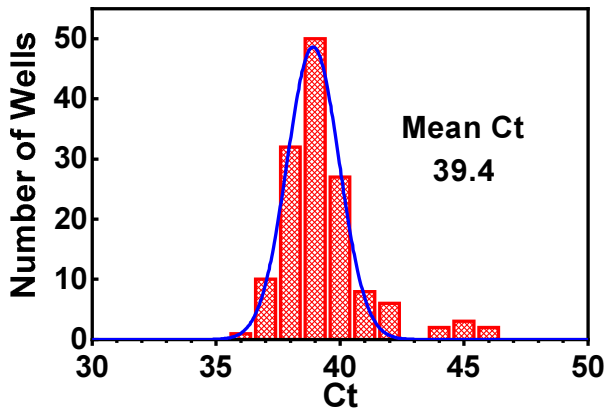

Figure S4. Activity distribution of single telomerase complexes detected in mouse embryo fibroblast (MEF) cells. A MEF cell lysate equivalent to 260 cells was diluted to three 384-well PCR plate and the telomerase activity in each well was measured, yielding 141 telomerase positive wells. The calculated mean telomerase enzyme per cell was 0.54 (141/260). 

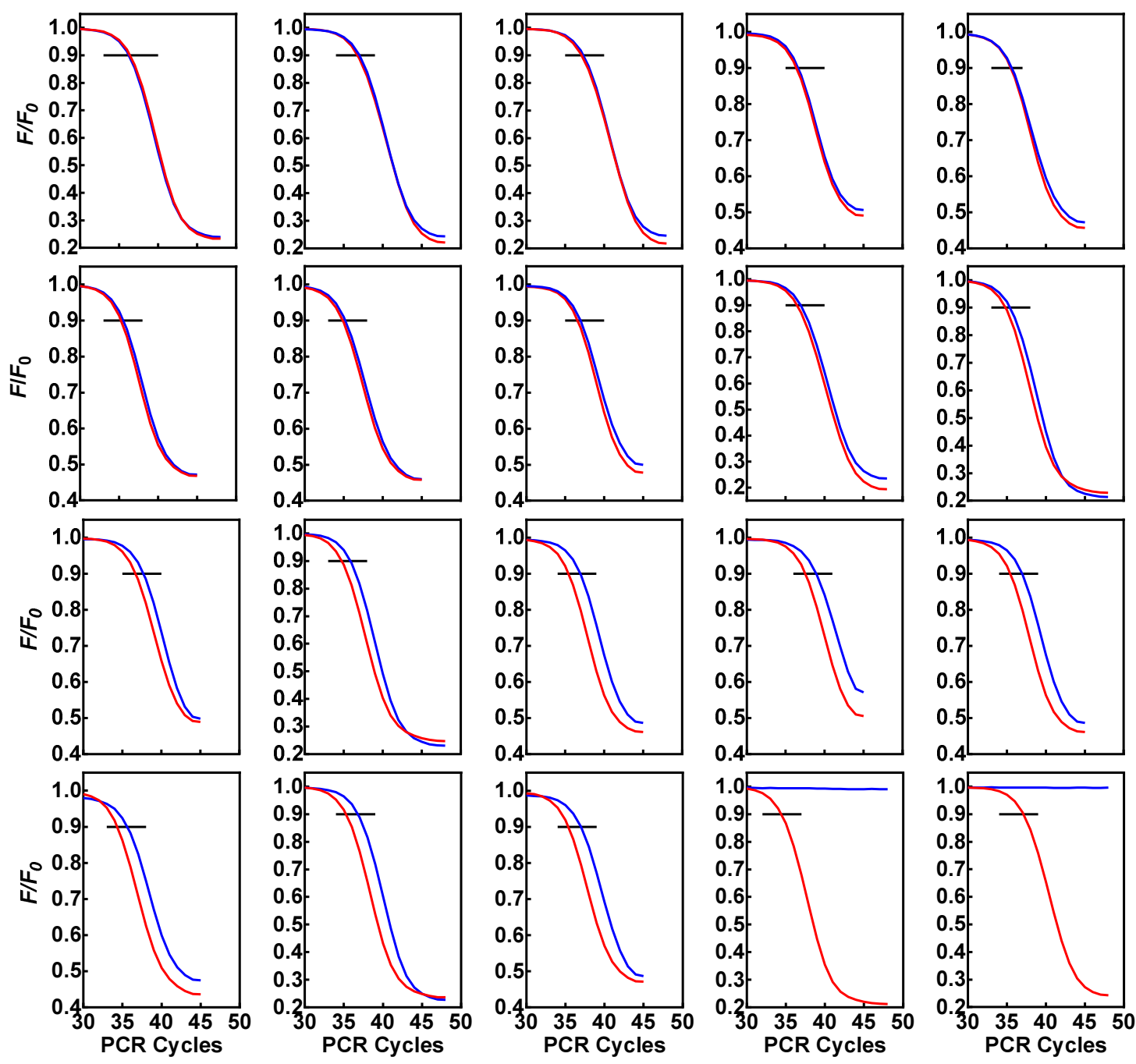

Figure S5. Asymmetric partitioning or loss of telomerase activity in offsprings observed at the 2-cell stage of mouse embryo development. Cells were prepared and assayed for telomerase activity as in Figure 7. 


\section{References}

(1) Kim, N. W.; Piatyszek, M. A.; Prowse, K. R.; Harley, C. B.; West, M. D.; Ho, P. L.; Coviello, G. M.; Wright, W. E.; Weinrich, S. L.; Shay, J. W., Specific association of human telomerase activity with immortal cells and cancer. Science 1994, 266, 2011-2015.

(2) Wright, W. E.; Shay, J. W.; Piatyszek, M. A., Modifications of a telomeric repeat amplification protocol (TRAP) result in increased reliability, linearity and sensitivity. Nucleic Acids Res. 1995, 23, 3794-3795.

(3) Aldous, W. K.; Grabill, N. R., A fluorescent method for detection of telomerase activity. Diagn. Mol. Pathol. 1997, 6, 102-110.

(4) Gan, Y.; Lu, J.; Johnson, A.; Wientjes, M. G.; Schuller, D. E.; Au, J. L., A quantitative assay of telomerase activity. Pharm. Res. 2001, 18, 488-493.

(5) Dalla Torre, C. A.; Maciel, R. M.; Pinheiro, N. A.; Andrade, J. A.; De Toledo, S. R.; Villa, L. L.; Cerutti, J. M., TRAP-silver staining, a highly sensitive assay for measuring telomerase activity in tumor tissue and cell lines. Braz. J. Med. Biol. Res. 2002, 35, 65-68.

(6) Savoysky, E.; Akamatsu, K.; Tsuchiya, M.; Yamazaki, T., Detection of telomerase activity by combination of TRAP method and scintillation proximity assay (SPA). Nucleic Acids Res. 1996, 24, 1175-1176.

(7) Hirose, M.; Abe-Hashimoto, J.; Ogura, K.; Tahara, H.; Ide, T.; Yoshimura, T., A rapid, useful and quantitative method to measure telomerase activity by hybridization protection assay connected with a telomeric repeat amplification protocol. J. Cancer Res. Clin. Oncol. 1997, 123, 337-344.

(8) Uehara, H.; Nardone, G.; Nazarenko, I.; Hohman, R. J., Detection of telomerase activity utilizing energy transfer primers: comparison with gel- and ELISA-based detection. Biotechniques 1999, 26, 552-558.

(9) Mayfield, M. P.; Shah, T.; Flannigan, G. M.; Hamilton Stewart, P. A.; Bibby, M. C., Telomerase activity in malignant and benign bladder conditions. Int. J. Mol. Med. 1998, 1, 835840.

(10) Elmore, L. W.; Forsythe, H. L.; Ferreira-Gonzalez, A.; Garrett, C. T.; Clark, G. M.; Holt, S. E., Real-time quantitative analysis of telomerase activity in breast tumor specimens using a highly specific and sensitive fluorescent-based assay. Diagn. Mol. Pathol. 2002, 11, 177-185. 